\title{
CHROMOSOMES OF SOME PUERTO RICAN \\ DISONYCHINA AND OEDIONYCHINA \\ (COLEOPTERA: CHRYSOMELIDAE: ALTICINAE: OEDIONYCHINI): EVOLUTIONARY IMPLICATIONS
}

\author{
By NiILo VirkKI ${ }^{1}$, JoRge A. SANTIAGo-Blay ${ }^{2}$ \\ AND SHAWN M. ClaRK ${ }^{3}$
}

\section{INTRODUCTION}

Bechyné and Springlová de Bechyné (1966) divided the tribe Oedionychini into the subtribes Disonychina and Oedionychina based, mainly, on thoracic and hind tarsal structures. This classification is supported also on cytological grounds (Virkki 1988b, 1989b). The Oedionychini, a lineage that shows some of the most interesting chromosomal relationships within the Coleoptera (Smith and Virkki 1978, Virkki 1985, 1988a, 1989a), is cytologically characterized by asynaptic sex chromosomes in male meiosis, increased spermatocyte size, and, in correlation with it, fewer spermatozoa per bundle (spz/b) (Virkki 1988a). The inferred polarity of the last character points to Oedionychina $(\mathrm{spz} / \mathrm{b}=16)$ as relatively derived (Disonychina, $\mathrm{spz} / \mathrm{b}=32$ ). The Oedionychini is considered the most derived tribe of the Alticinae (J. Bechyné 1968 pers. comm.). A correlation of characters on the internal reproductive system of the Chrysomelidae has recently been discussed by Suzuki (1989).

Meiograms and chromosomal illustrations of four Puerto Rican Disonychina and three Oedionychina are presented. Phylogenetic implications of these finds are discussed.

\footnotetext{
1 Department of Crop Protection, Agricultural Experiment Station, P. O. Box 21360, Río Piedras, PR 00928-1360

2 Department of Entomological Sciences, University of California, Berkeley, CA 94720-0001 USA

${ }^{3}$ West Virginia Department of Agriculture, State Capitol, Charleston, WV 25305 USA

Manuscript received 8 March 1991.
} 


\section{METHODS}

Species, host plants (author and family), sample size, and collecting data are as in Table 1. Nomenclature and protocols follow Virkki, et al. (1992).

\section{RESULTS}

Disonychina. This Neotropical subtribe (Bechyné and Springlová de Bechyné 1966) comprises seven genera of which, only two, Disonycha Blake and Phenrica Bechyné, have been partially studied cytologically (Virkki 1989b). Autosomes (13-30 pairs) have been found to combine with a sex chromosome system consisting of one Xy bivalent and one or two additional, univalent, $\mathrm{X}$ chromosome(s) $(\mathrm{Xy}+\mathbf{n X}, \mathrm{n}=1$ or 2$)$.

\section{Disonycha spilotrachela Blake}

This is perhaps the most polyphagous Puerto Rican Disonycha (Table 1). A dense and persisting population feeds on Turnera ulmifolia (Turneraceae) on the south coast of Laguna Tortuguero. This species has been reported for Cuba, Haiti, and Puerto Rico (Wolcott 1948; Blake 1933, 1955; Wilcox 1983).

Meiogram (Fig. 1A) and MI (Fig. 2B): $13+\mathrm{X}_{1} \mathrm{y}+\mathrm{X}_{2}$. The segregation results in $15(2 \mathrm{X})$ and in $14(\mathrm{y})$ chromosomes at $\mathrm{M}$ II plates (Figs. 3E, F, respectively).

Karyogram (Virkki 1988b): $2 \mathrm{n}=30(4 \mathrm{X})$ on females, $2 \mathrm{n}=29(2 \mathrm{X}, \mathrm{y})$ on males. All chromosomes are metacentric. Nucleolar organizing regions (NOR's) are located on a homologous pair of medium-sized autosomes.

\section{Disonycha comma White}

This species also lives on Hispaniola, and perhaps has invaded Puerto Rico recently. Possibly, D. comma is synonymous with $D$. peruana Jacoby that inhabits mainland areas of tropical America. The first Puerto Rican specimens were collected in 1988 and now it is becoming common in the south coast of Laguna Tortuguero where it thrives on Croton lobatus (Euphorbiaceae), a common weed. In captivity, it has accepted only Passiflora murucuja (Passifloraceae) among the various Passiflora spp. offered (J. Escudero 1989 pers. comm., see also Jolivet 1991). 


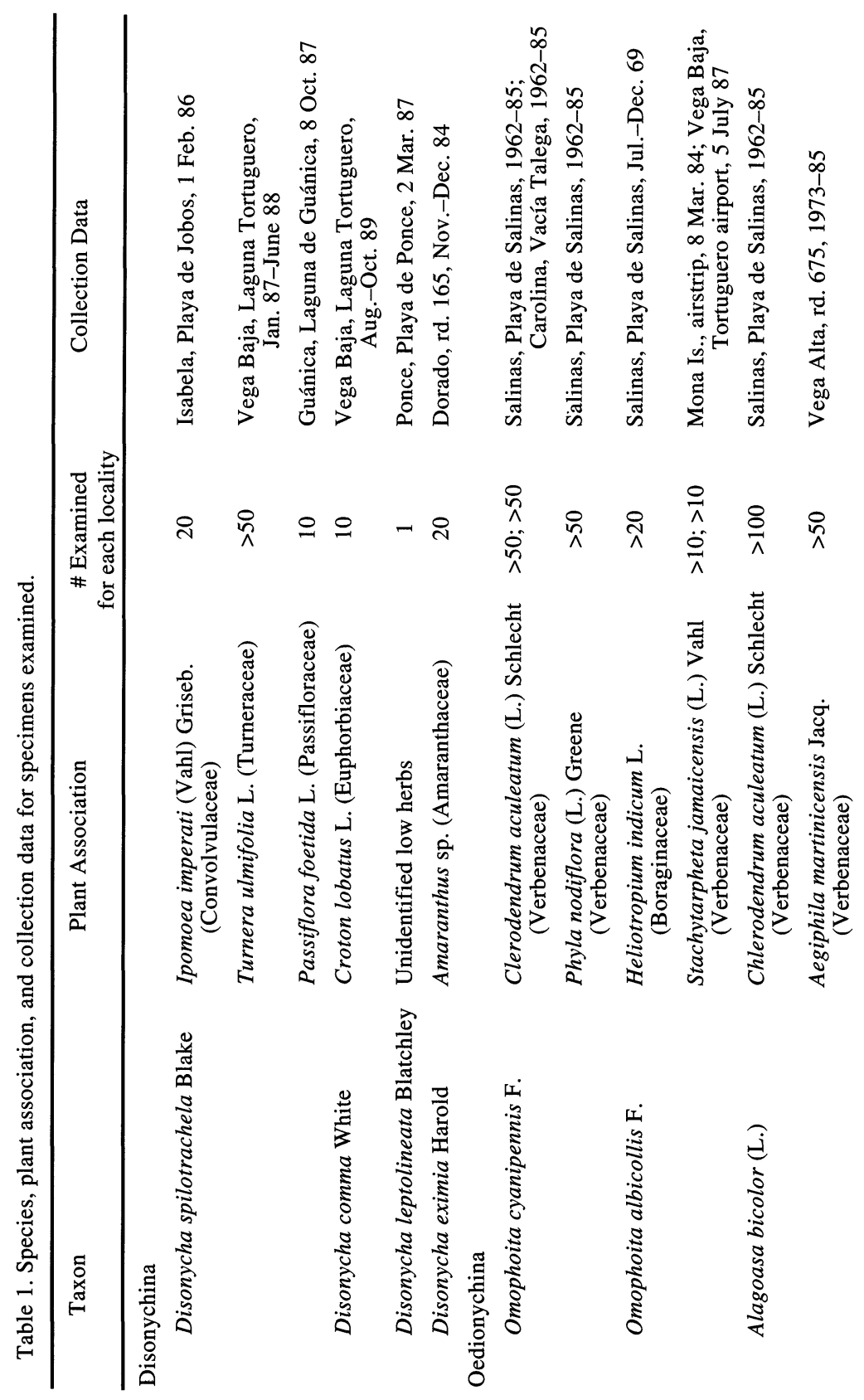




\section{A $3250325 \times 2582 x_{x y}^{2} x$

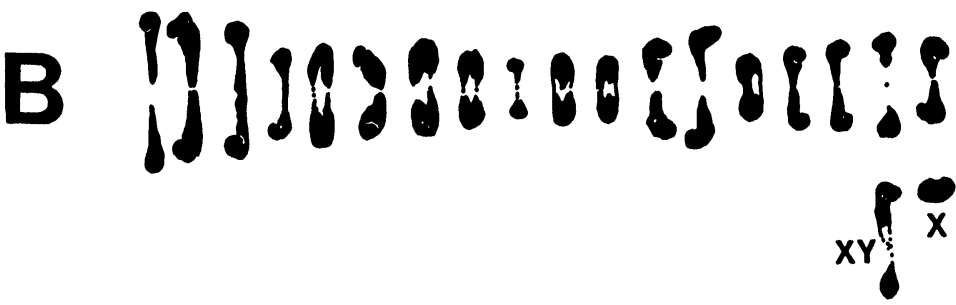

\section{C $18828288+182+882880$ $x y+x$}

\section{D $11400260159000+2101$ $x \times 8 \times \frac{9}{x}$}

Fig. 1. Meiograms of some Puerto Rican Disonychina. A. Disonycha spilotrachela, $13+\mathrm{X}_{1} \mathrm{y}+\mathrm{X}_{2}$. B. D. comma, $18+\mathrm{X}_{1} \mathrm{y}+\mathrm{X}_{2}$. C. D. leptolineata, $19+\mathrm{X}_{1} \mathrm{y}+\mathrm{X}_{2}$. D. D. eximia, $19+\mathrm{X}_{1} \mathrm{y}+\mathrm{X}_{2}+\mathrm{X}_{3}$.

Meiogram (Fig. 1B) and M I (Fig. 2C): $18+\mathrm{X}_{1} \mathrm{y}+\mathrm{X}_{2}$. All autosomes are metacentric and most are capable of forming ring bivalents, a sign of more than one crossover on a chromosome.

Karyogram (Figs. 4, 5): $2 \mathrm{n}=40(4 \mathrm{X})$ on females, $2 \mathrm{n}=39(2 \mathrm{X}, \mathrm{y})$ on males. All autosomes and, at least, $\mathrm{X}_{1}$ are metacentric.

Disonycha leptolineata Blatchley

Formerly unknown from Puerto Rico, this species became quite abundant in the Ponce region some years ago (J. Micheli 1990 pers. comm.) but it is seldom seen nowadays. This population growth pattern suggests a recent invasion, followed by a rapid increase, and an effective checking by natural enemies (van den 


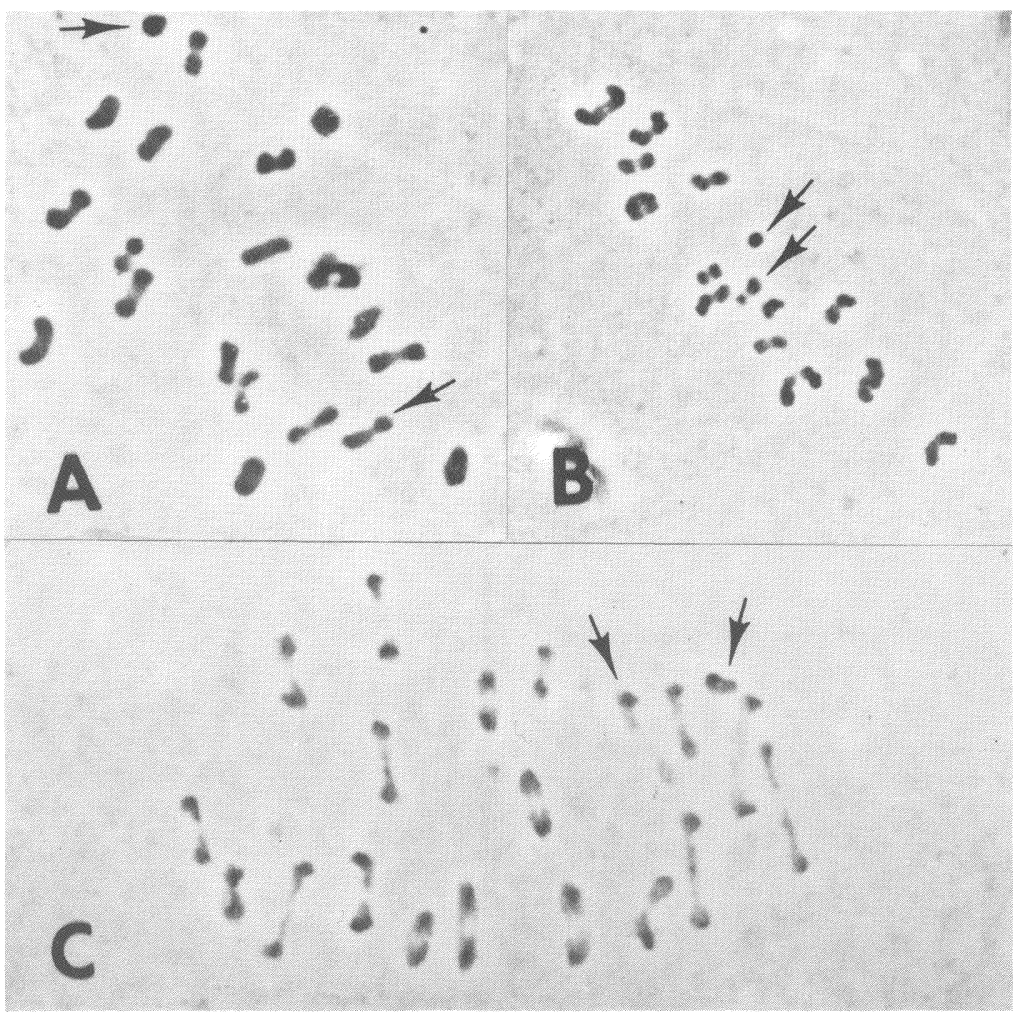

Fig. 2. First meiotic metaphase in three Disonycha spp. Phase contrast. On A and $\mathrm{B}$, the lowermost arrows point the $\mathrm{X}_{1} \mathrm{y}$; on $\mathrm{C}$, the right hand arrow. A. D. leptolineata, $19+\mathrm{X}_{1} \mathrm{y}+\mathrm{X}_{2} .(1435 \times)$ B. D. spilotrachela, $13+\mathrm{X}_{1} \mathrm{y}+\mathrm{X}_{2} .(1168 \times)$ C. D. comma, $18+\mathrm{X}_{1} \mathrm{y}+\mathrm{X}_{2} \cdot(1205 \times)$

Bosch, et al. 1982). This species is known from the U.S.A. to Mexico and Guatemala.

Meiogram (Fig. 1C) and M I (Fig. 2A): $19+X_{1} y+X_{2}$. This is an amendment of the former preliminary count $18+\mathrm{X}_{1} \mathrm{y}+\mathrm{X}_{2}$ (Virkki $1988 \mathrm{~b})$. The "telephone-handle" shape of many bivalents suggests that they are formed by metacentric autosomes. Segregation to $21(2 \mathrm{X})$ and $20(\mathrm{y})$ is confirmed by M II (Fig. 3A and B). 


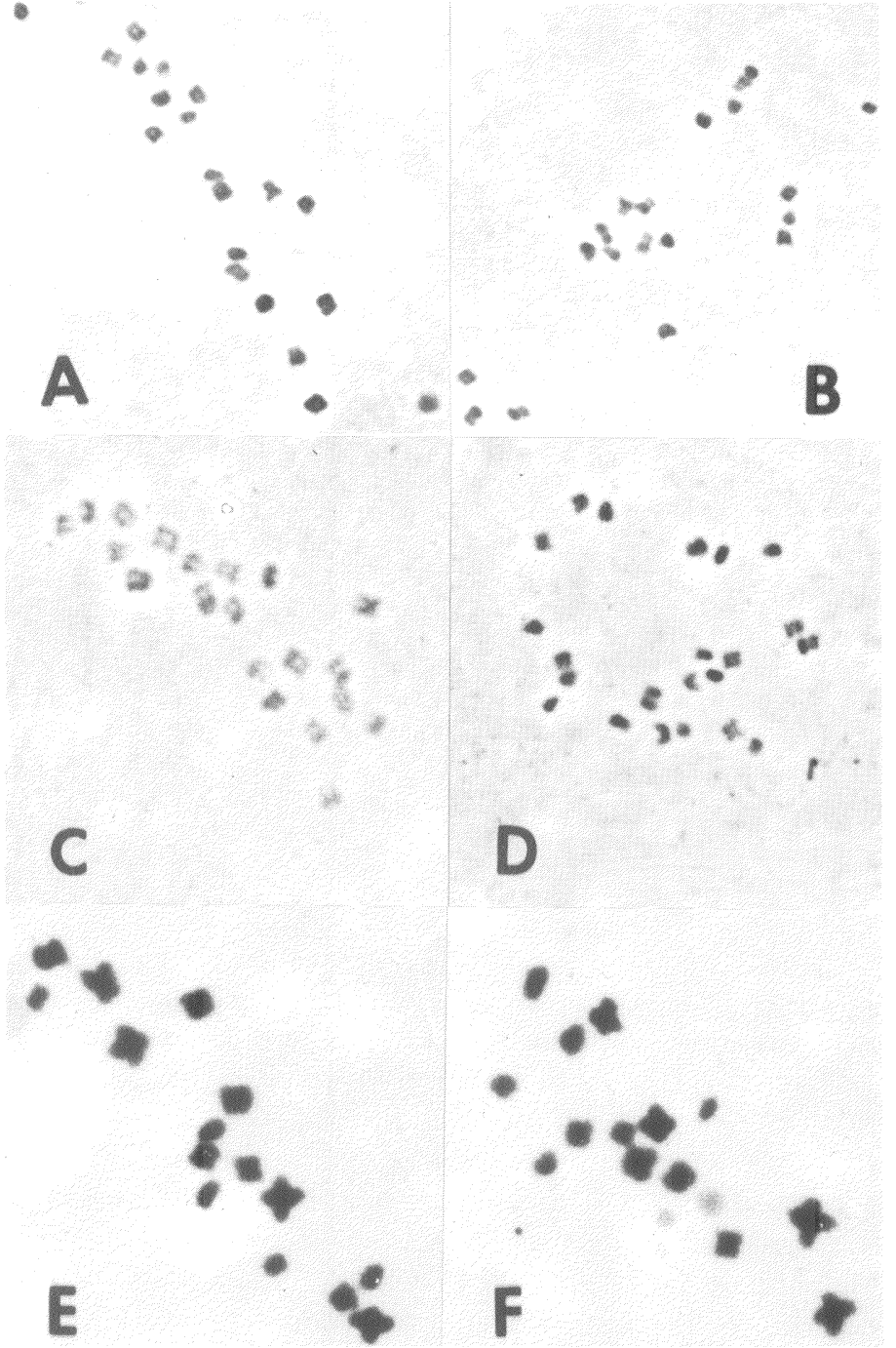

Fig. 3. Second meiotic metaphase in three Disonycha spp. Phase contrast. Identification of the sex chromosomes is not attempted. A and B. D. leptolineata. (1264X and $1018 \times$, respectively.) A shows 21 chromosomes (19 autosomes, two $\mathrm{X}$ chromosomes); B, 20 chromosomes (19 autosomes and one y chromosome). C and D. D. eximia. $(1018 \times) \mathrm{C}$ shows 20 chromosomes (19 autosomes and one y chromosome); D, 22 chromosomes (19 autosomes and three X chromosomes). E and F. D. spilotrachela $1791 \times)$ E shows 15 chromosomes (13 autosomes and two $\mathrm{X}$ chromosomes); F, 13 autosomes and one y chromosome. 


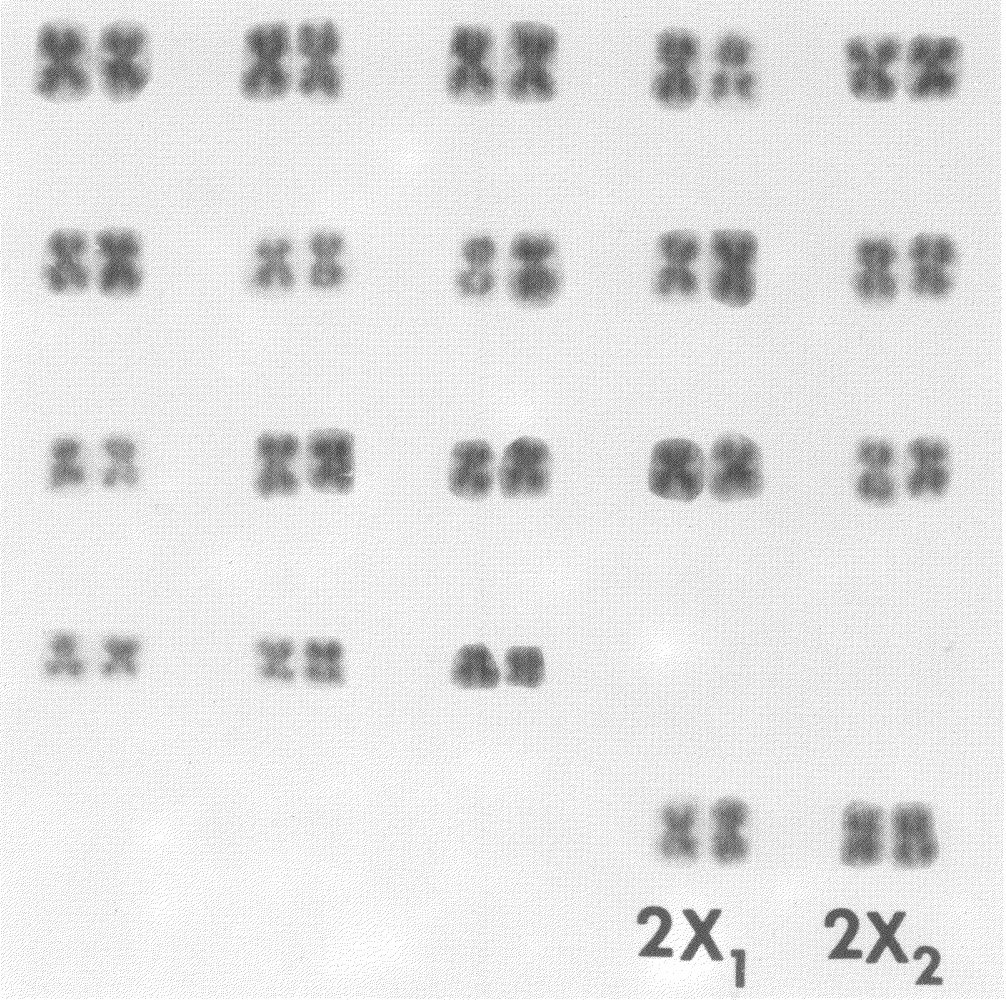

Fig. 4. Karyogram of female D. comma. $2 \mathrm{n}=40(4 \mathrm{X})$.

\section{Disonycha eximia Harold}

Apart from D. chlorotica (Olivier) and D. weisei Csiki, both of which likely belong in other genera and neither of which has been recognized in recent years, this is the only non-vittate Disonycha (Blake 1955) known from Puerto Rico. This species is distributed from Costa Rica to Panamá. Wolcott (1948) suspected that this species may have arrived from Hispaniola in Puerto Rico early in the century. Undoubtedly, this species is now well established in Puerto Rico.

Meiogram (Fig. 1D) and M I (Virkki 1988b): $19+X_{1} y+X_{2}+X_{3}$. This is the highest chromosome number among Puerto Rican Disonychini. In closely related species with low and higher chromosome numbers, high numbers tend to be associated with the 


\section{8 8 882 82 * $8 \pi$ 8 1 8 18

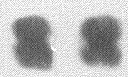 4 8

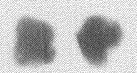 0 14

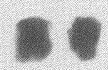

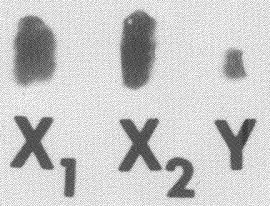

Fig. 5. Karyogram of male D. comma. $2 \mathrm{n}=39(2 \mathrm{X}, \mathrm{y})$.

existence of acro- or telocentric chromosomes (Robertson's rule), but in this species most chromosomes look metacentric and are capable of ring bivalent formation. The segregation to $22(3 \mathrm{X})$ and 20 (y) is confirmed by M II (Fig. 3C and D).

Karyogram (Virkki 1988b): $2 \mathrm{n}=44(6 \mathrm{X})$ on females, $2 \mathrm{n}=42(3 \mathrm{X}, \mathrm{y})$ on males.

Oedionychina. This Pantropical subtribe has several Neotropical genera cytologically characterized as follows: typically with $2 \mathrm{n}=22(\mathrm{X}, \mathrm{y})$ and $10+\mathrm{X}+\mathrm{y}$ in males (Petitpierre et al. 1988), giant sex chromosomes segregating from a "distance bivalent" in male meiosis, $16 \mathrm{spz} / \mathrm{b}$, the lowest number known in Coleoptera, and very large spermatocyte I (Smith and Virkki 1978, Virkki 1985, Virkki and Denton 1987). Aggregation of nuclear pores to "nuclear 
sieve complexes" (Virkki and Kimura 1978) in the growing spermatocyte I characterizes Alagoasa spp. and many other Neotropical genera formerly included in Oedionychus spp. (Virkki 1976). The inferred polarity (Stephens 1980) of the latter character points to Alagoasa and "Oedionychus" as more derived than Omophoita, which shows random distribution of nuclear pores in their spermatocyte I.

The orientation and segregation of the giant univalent sex chromosomes, as well as the growth of spermatocyte $I$ in Oedionychina, have theoretical and phylogenetic implications (Smith and Virkki 1978, Virkki 1970, 1988a).

\section{Omophoita cyanipennis cyanipennis (Fabricius)}

This oligophagous beetle feeds principally on the verbenaceans Clerodendrum aculeatum and Phyla nodiflora, especially on borders of mangroves and other wetlands where the host plants are sympatric (Virkki 1980). It has a West Indian to southern North America distribution (Wilcox 1983). Puerto Rican samples are largely comprised of individuals with unicolored elytra; individuals with white spots are rare (Virkki 1980). A spotted color morph O. c. octomaculata (Crotch) prevails from Texas to Florida (U.S.A.), and perhaps on some of the other Caribbean islands (Blake 1931, Wilcox 1983).

Meiogram (Fig. 6A) and M I (Virkki 1979b): 10+X+y. Spermatogonial metaphases show $2 \mathrm{n}=22(\mathrm{X}, \mathrm{y})$ (Virkki 1979b). As found for many Omophoita spp. (Virkki 1983), the Y chromosome is acrocentric or submetacentric, having, in contrast to $\mathrm{X}$, unequal arms. Profiles of autosomal bivalents show all chromatids united by what may be a chiasma terminalized during a preceding diffuse diplotene, if not an original terminal contact. Cross or ring bivalents have never been observed. Each chromatid shows a "telephone-handle" shape in the large bivalent closest to the sex chromosomes, but, where the free arm is short, it projects polewards leaving the centric gap equatorialwards from it. Jamaican samples of $O$. c. octomaculata have the same karyotype as $O$. $c$. cyanipennis from Puerto Rico (Virkki, unpubl.).

Idiogram, based on measurements of A II chromosomes. Sex chromosomes assume nearly 53\% of total karyotype length, all chromosomes are metacentric (Virkki 1979b). 


\section{A $182: 2 \times 8: 2$}
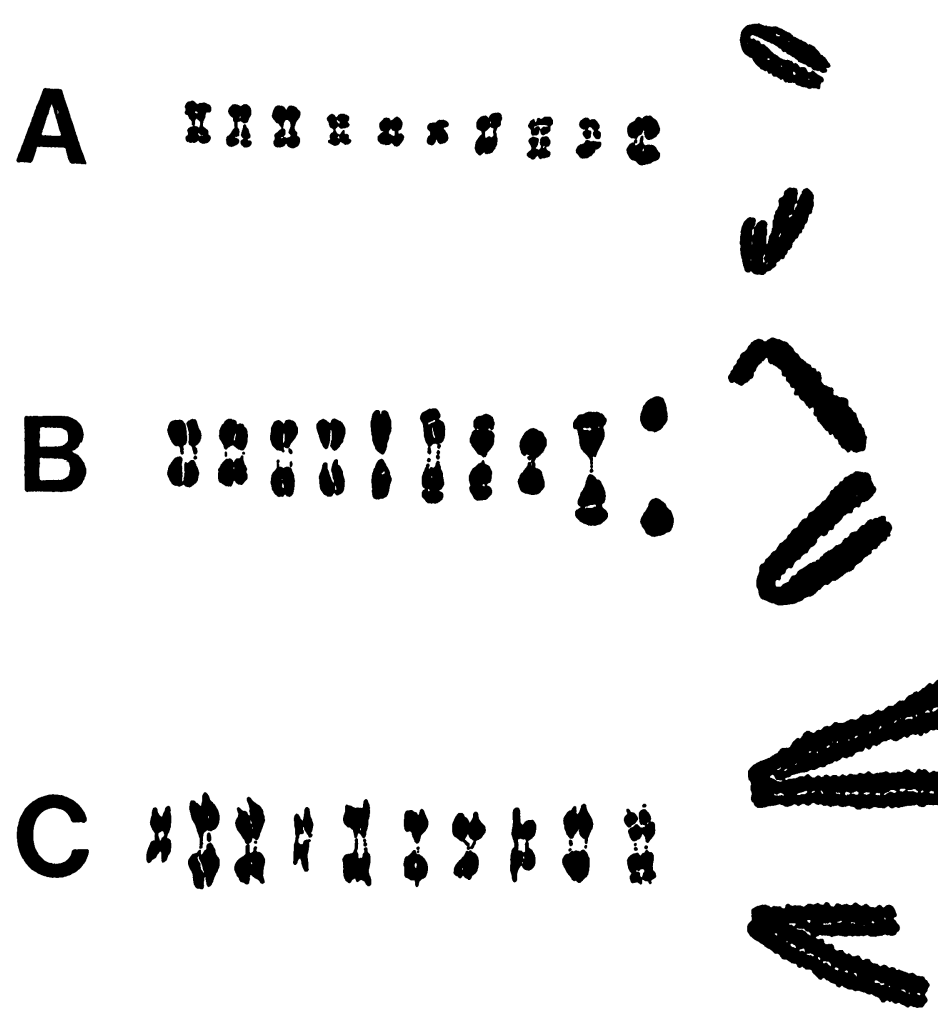

Fig. 6. Meiogram of three Puerto Rican Oedionychina. 10+X+y. A. Omophoita cyanipennis. B. O. albicollis. C. Alagoasa bicolor.

\section{Omophoita albicollis (Fabricius)}

This beetle lives in drier habitats and it is more sporadically found than $O$. c. cyanipennis. It has been found feeding of Stachytarpheta jamaicensis (Verbenaceae) near the air strip of Mona Island and in the abandoned military air strip at Tortuguero. Heliotropium indicum (Boraginaceae) is a secondary host (Virkki 1980).

Meiogram (Fig. 6B) and M I (Smith and Virkki 1978): 10+X+y. The $\mathrm{Y}$ chromosome has even more unequal arms than in $O$. c. cyanipennis. A desynaptic autosome pair depicted closest to the sex 


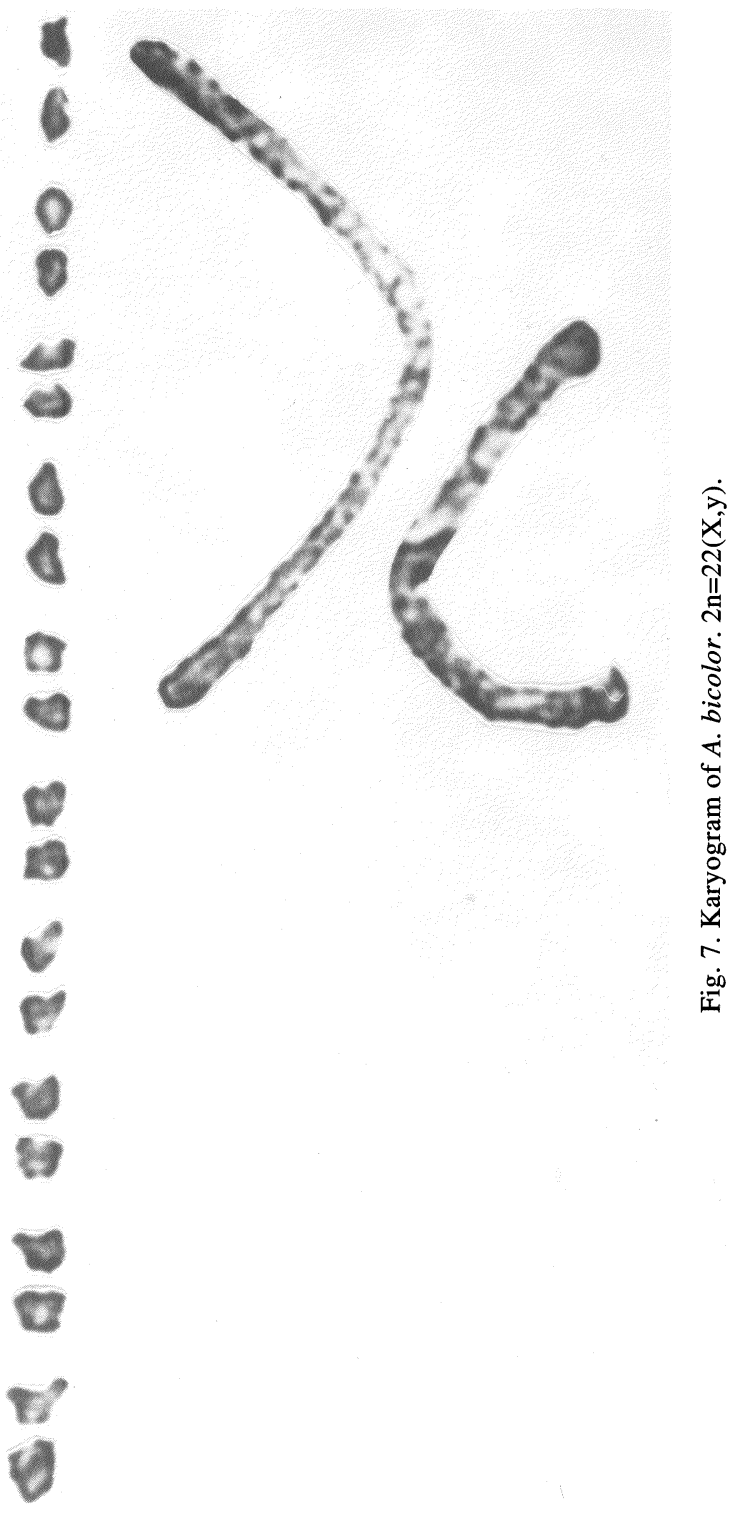


chromosomes (Fig. 6B) is often seen in Oedionychina from the Puerto Rico region. Because such univalents do not move to the poles but remain facing one another not far from the equator, they may show incipient distance pairing rather than asynapsis or precession.

Alagoasa bicolor (L.)

Compared to $O$. c. cyanipennis and $O$. albicollis, this is a sedentary species that seldom leaves its host plant. It is sympatric with O. c. cyanipennis, and it feeds on C. aculeatum and Aegiphila martinicensis (both Verbenaceae), the latter not associated with wetlands. In spite of published records from other islands, the distribution of this species is probably limited to Puerto Rico and the Virgin Islands (Blake 1940). Some aspects of the life history, ecology, and behavior of this species in Puerto Rico have been studied (Virkki 1979a, 1980; Virkki and Zambrana 1980, 1983).

Meiogram (Fig. 6C) and M I (Virkki 1970, 1989a): 10+X+y. Both sex chromosomes are nearly mediocentric, $\mathrm{X}$ slightly larger than Y. All autosomes look acro- or telocentric.

Karyogram (Fig. 7) and spermatogonial mitosis (Virkki 1970): $2 \mathrm{n}=22(\mathrm{X}, \mathrm{y})$. The autosomes, which have distal collochores (Virkki 1989a) in meiosis, do not show proximal collochores in these mitoses either, but their chromatids do not immediately open to stop at the final contact on the telomeres. There are some "sticky bridges" that slow down the separation of the chromatids. We have studied a sample taken from C. aculeatum in Emmaus, St. John (United States Virgin Islands), that shows the same karyotype as the Puerto Rican sample.

Idiogram. The sex chromosomes comprise $52 \%$ of the total karyotype length, all autosomes are telocentric (M. Mojica 1990 pers. comm.). M II chromosomes are currently being studied.

\section{DISCUSSION}

The cytological, hypothetical synapomorphic characters of Oedionychini (Disonychina and Oedionychina) are summarized in Fig. 8. It should be noted that a $10+\mathrm{X}+\mathrm{y}$ meioformula has appeared in Omophoita and in Alagoasa, constituting a parallelism. Also, the status of the nuclear pore distribution in Asphaera is uncertain (Virkki 1976); morphological characters (Scherer 1983) seem to 


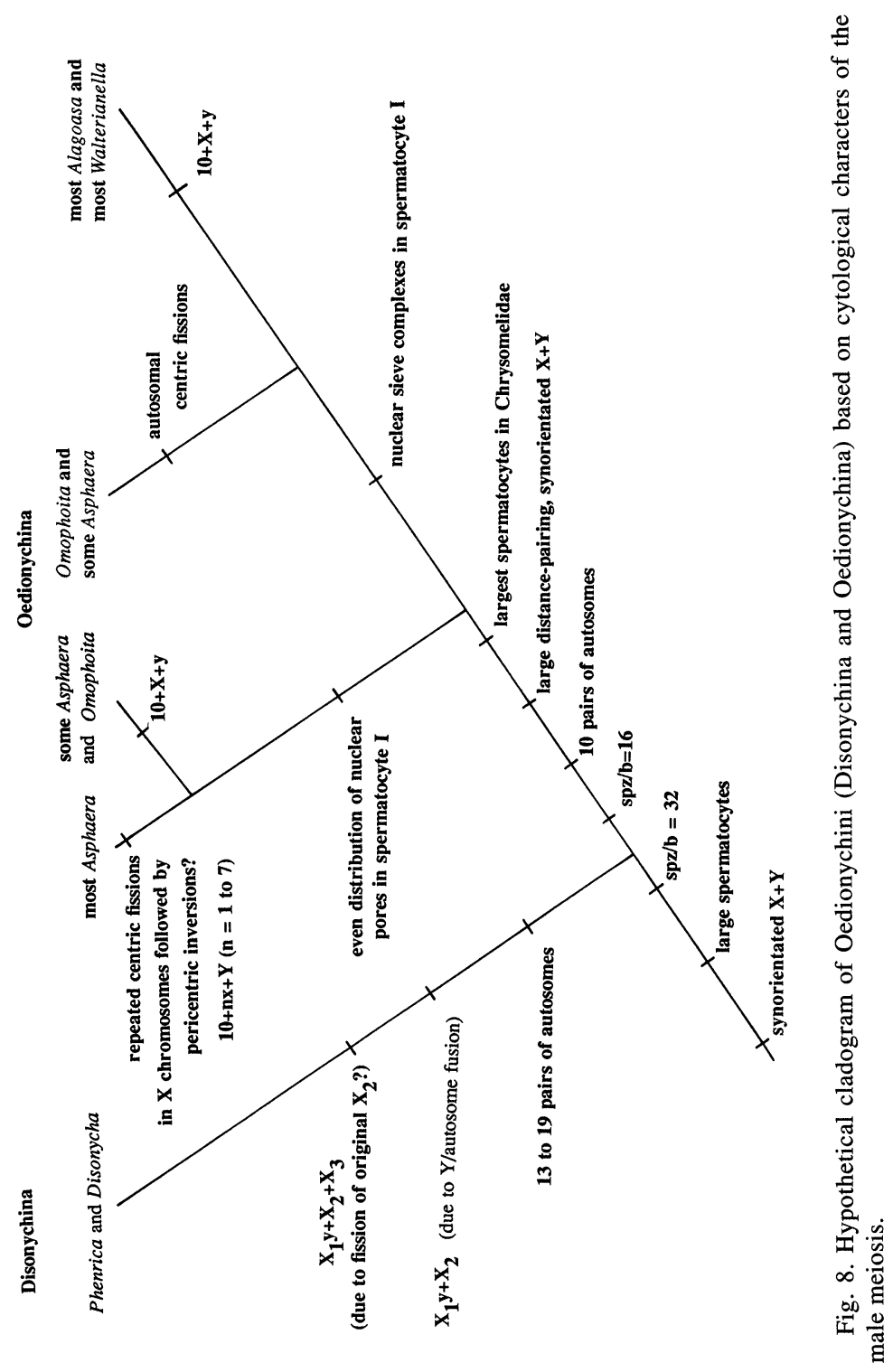


support our hypothetical placement. Virkki (1970, 1988a) suggested that the evolution of these Disonychina and Oedionychina can be tracked to some genera related to Altica and Syphraea, the putative primitive "tribal groupings" Alticini and Hermaeophagini, where male meioformulae $11+\mathrm{X}+\mathrm{y}$ occur. It should be noted that the use of tribal names in the Alticinae is highly suspect and not well founded at this point (D. Furth 1991 pers. comm.). A common ancestor for Disonychina and Oedionychina should be looked for among relatively remote forms having karyotypes like those in Stenophyma sp., with unpaired, synorientated sex chromosomes of moderate size (Virkki 1970). A translocation of such a Y chromosome on an autosome would immediately produce a neo-system $\mathrm{X}_{1} \mathrm{y}+\mathrm{X}_{2}$, as found in Disonychina. Oedionychina would have evolved without such translocation, under enormous increase in the size of both sex chromosomes. It seems feasible that a simultaneous increase of the spermatocyte size occurred in response to the increasing size of the $\mathrm{Y}$ chromosome, which has bands active in the diplotenic growth stage of spermatocyte I (Virkki and Denton 1987). Cell size and genome size increase have been positively correlated in succulent plants (De Rocher et al. 1990). Intraspecific variation of these parameters is similarly correlated in Tribolium (Coleoptera: Tenebrionidae), a genus showing spermatocytes of conventional size (Alvarez-Fuster, et al. 1991). Since the very large spermatocytes of Oedionychina would not fit in a cyst formed by only two or four cyst wall cells, alternative rearrangements became necessary: either to enlarge the cyst through additional cell growth or multiplication of the cyst wall cells, or to reduce the number of spermatocytes per cyst. The latter alternative was realized, in continuation of a trend already established on this inferred evolutionary lineage. Among the chromosomally most advanced Oedionychina are Asphaera spp., where distance sex multivalents occur (Petitpierre et al. 1988, Vidal 1984). These were usually noted $X+n y(n=1-7)$, but since females became available for study, the $X$ chromosome was found to be multiple: $\mathrm{nx}+\mathrm{Y}$ (Virkki and Santiago-Blay, unpubl.). The multiple chromosomes are relatively small but of different size, suggesting a repeated sequence of centric fissions of formerly large chromosomes followed by pericentric inversions. Other advanced genera are Walterianella Bechyné, where autosomal centric fissions have 
led to $22+\mathrm{X}+\mathrm{y}$ karyotypes (Petitpierre et al. 1988), and an undescribed Alagoasa with $5+\mathrm{X}+\mathrm{Y}$ due to autosomal centric fusions (Virkki and Santiago, unpubl.).

The chromosomal and cytological unorthodoxies of Oedionychini, and especially of Oedionychina, warrant a comparative study of alleged related genera (see Seeno and Wilcox 1982, pp. 139-141), particularly the Old World Oedionychus.

\section{SUMMARY}

The Puerto Rican beetles of the tribe Oedionychini are cytologically typical of the inferred sister subtribes Disonychina and Oedionychina. In four Disonychina (Disonycha spilotrachela, D. comma, D. leptolineata, and D. eximia), metacentric autosomes prevail. Interspecific differences are expressed mainly in the diploid number, from $2 \mathrm{n}=30(4 \mathrm{X})$ ९ / 29(2X,y) o to $2 \mathrm{n}=44(6 \mathrm{X})$ ᄋ / $42(3 \mathrm{X}, \mathrm{y})$ or. The sex chromosome association in male meiosis is either $\mathrm{X}_{1} \mathrm{y}+\mathrm{X}_{2}$ or $\mathrm{X}_{1} \mathrm{y}+\mathrm{X}_{2}+\mathrm{X}_{3}$. Disonycha leptolineata and $D$. comma are new records for Puerto Rico. In contrast, the three species of Oedionychina (Omophoita c. cyanipennis, O. albicollis, Alagoasa bicolor), have $2 \mathrm{n}=22(\mathrm{X}, \mathrm{y})$, with a simple distance sex bivalent in male meiosis $(\mathrm{X}+\mathrm{y})$. The interspecific differences are mainly due to a different centromere position. We suggest that karyotypes as those encountered in contemporary Stenophyma gave rise to Oedionychini by increase in size of sex chromosomes and/or by chromosomal rearrangements.

\section{RESUMEN}

Los escarabajos puertorriqueños de la tribu Oedionychini son citologicamente típicos de las subtribus hermanas inferidas Disonychina y Oedionychina. En cuatro Disonychina (Disonycha spilotrachela, D. comma, D. lepotolineata, y D. eximia), estudiadas, prevalecen los autosomas metacéntricos. Las diferencias interespecíficas ocurren mayormente en el número diploide, desde $2 \mathrm{n}=30(4 \mathrm{X})$ \& / 29(2X,y) o hasta $2 \mathrm{n}=44(6 \mathrm{X})$ ᄋ / 42(3X,y) ơ. La asociación de cromosomas sexuales en la meiosis de los machos es $\mathrm{X}_{1} \mathrm{y}+\mathrm{X}_{2}$ o $\mathrm{X}_{1} \mathrm{y}+\mathrm{X}_{2}+\mathrm{X}_{3}$. Disonycha leptolineata y D. comma son nuevos registros para Puerto Rico. Por contraste, las tres especies de Oedionychina (Omophoita c. cyanipennis, O. albicollis, 
Alagoasa bicolor), tienen $2 \mathrm{n}=22(\mathrm{X}, \mathrm{y})$, con un bivalente sexual de distancia sencillo en la meiosis del macho $(\mathrm{X}+\mathrm{y})$. Las diferencias interespecíficas se deben mayormente a las deferencias en la posición del centrómero. Sugerimos que cariotipos como los encontrados en Stenophyma contemporáneos originaron Oedionychini mediante el crecimiento de los cromosomas sexuales y/o las reordenaciones cromosómicas.

\section{Literature Cited}

Alvarez-Fuster, A., C. Juan, And E. PetitPierre

1991. Genome size in Tribolium flour-beetles: inter- and intraspecific variation. Genet. Res. 58: 1-5.

BeChyné, J. AND B. SPRinglova De BeChyné

1966. Evidenz der bisher bekannten Phenrica-Arten (Col. Phytophaga, Alticidae). Entomol. Tidskr. 87: 142-170.

BLAKE, D. H.

1931. Notes on West Indian and Central American flea-beetles (Halticinae). Bull. Brooklyn Ent. Soc. 1931: 76-83.

1933. Revision of the beetles of the genus Disonycha occurring in America North of Mexico. Proc. U. S. Natl. Mus. 82: 1-66.

1940. Oedionychis fasciata (Fabr.) and closely related species. Proc. Entomol. Soc. Wash. 42: 170-175.

1955. A revision of the vittate species of the chrysomelid genus Disonycha from the Americas south of the United States. Proc. U. S. Natl. Mus. 104: $1-86$.

De Rocher, E. J., K. R. Harkins, D. W. Galbraith and H. J. Bohnert

1990. Developmentally regulated systemic endopolyploidy in succulents with small genomes. Science 250: 99-101.

JOLIVET, P.

1991. Selection tropique chez les Alticinae (Coleoptera: Chrysomelidae) suite. Bull. mens. soc. Linn. Lyon 60(2): 53-72.

PetitPierre, E., C. Segarra, J. S. Yadav and N. VirkKi

1988. Chromosome numbers and meioformulae of Chrysomelidae. In, P. Jolivet, E. Petitpierre and T. S. Hsiao (edit.). Biology of the Chrysomelidae. Chap. 10. pp. 161-186. Kluwer Acad. Publ. Dordrecht, The Netherlands. $615 \mathrm{pp}$.

SCHERER, G.

1983. Diagnostic key for the Neotropical alticinae genera. Entomol. Arb. Mus. Frey 31/32: 1-89.

SEeno, T. N. AND J. A. WiLCoX

1982. Leaf beetle genera (Coleoptera: Chrysomelidae). Entomography 1: $1-221$.

SMITH, S. G., AND N. VIRKKI

1978. Animal Cytogenetics: Coleoptera. Edit. B. John. Borntraeger. Berlin-Stuttgart. 366 pp. 
STEVEns, P. F.

1980. Evolutionary polarity of character states. Ann. Rev. Ecol. Syst. 11: 333-358.

SUZUKI, K.

1989. Character correlation in the internal reproductive system of the family Chrysomelidae (Coleoptera). Entomography 6: 511-518.

VAN DEN BosCh, R., P. S. MesSENGer AND A. P. GUTIERREZ

1982. An introduction to biological control. Plenum Press. New York. 247 pp.

VIDAL, O. R.

1984. Chromosome numbers of Coleoptera from Argentina. Genetica 65: 235-239.

VIRKKI, N.

1970. Sex chromosomes and karyotypes of the Alticidae (Coleoptera). Hereditas 64: 267-282.

1976. Prophase of spermatocyte I in Oedionychina (Coleoptera). J. Agric. Univ. Puerto Rico 60:661-674.

1979a. Ovariole numbers in two Puerto Rican Oedionychina (Coleoptera). J. Agric. Univ. Puerto Rico 63: 50-56.

1979b. Response of an Oedionychina (Coleoptera) karyotype to acute gamma radiation. J. Agric. Univ. Puerto Rico 63: 116-149.

1980. Fleabeetles, especially Oedionychina, of a Puerto Rican marshland in 1969-72. J. Agric. Univ. Puerto Rico 64: 63-92.

1983. Banding of Oedionychina (Coleoptera: Alticinae) chromosomes: Cand Ag- bands. J. Agric. Univ. Puerto Rico 67: 221-255.

1985. The cytogenetic system of Oedionychina (Alticinae). Entomography 3 : $489-497$.

1988a. Cytotaxonomy of Alticinae. In, P. Jolivet, E. Petitpierre and T. S. Hsiao (edit.). Biology of the Chrysomelidae. Chap. 11, pp. 187-203. Kluwer Acad. Publ. Dordrecht, The Netherlands. 615 pp.

1988b. The sex chromosomes of Disonychina (Coleoptera, Alticinae): $\mathrm{Xy}+\mathbf{n X}$ systems. Cytobios 53: 43-55.

1989a. Proximal vs. distal collochores in coleopteran chromosomes. Hereditas 110: $101-107$.

1989b.On the cytological justification of the fleabeetle subtribes Oedionychina and Disonychina (Bechyné and Springlová de Bechyné 1966). Entomography 6: 545-550.

VIRKKI, N. AND A. DENTON

1987. Silver staining of the elements of spermatogenesis in Oedionychina (Chrysomelidae: Alticinae). Hereditas 106: 37-49.

VIRKKI, N. AND M. KIMURA

1978. Distribution of nuclear pores and perinuclear dense substances in spermatocytes I of some Oedionychina fleabeetles. BioSystems 10: 213-225.

VirkKi, N., J. A. SANTiago-Blay, AND E. G. Riley

1992. Chromosomes of Puerto Rican Hispinae and Cassidinae (Chrysomelidae). Coleops Bull. 46: 29-42. 
VIRKKI, N. AND I. ZAMBRANA

1980. Demes of a Puerto Rican fleabeetle, Alagoasa bicolor (L.), differing in mean body size and food plant association. J. Agric. Univ. Puerto Rico 64: 264-274.

1983. Life history of Alagoasa bicolor (L.) in indoor rearing conditions. Entomol. Arb. Mus Frey 31/32: 131-155.

WILCox, J. A.

1983. Family 129. Chrysomelidae. In, R. H. Arnett (ed.). Checklist of the beetles of North and Central America and the West Indies. pp. 1-166. Flora \& Fauna Publ. Florida.

WolcotT, G. N.

1948. The insects of Puerto Rico. Coleoptera. J. Agric. Univ. Puerto Rico 32: $225-414$. 

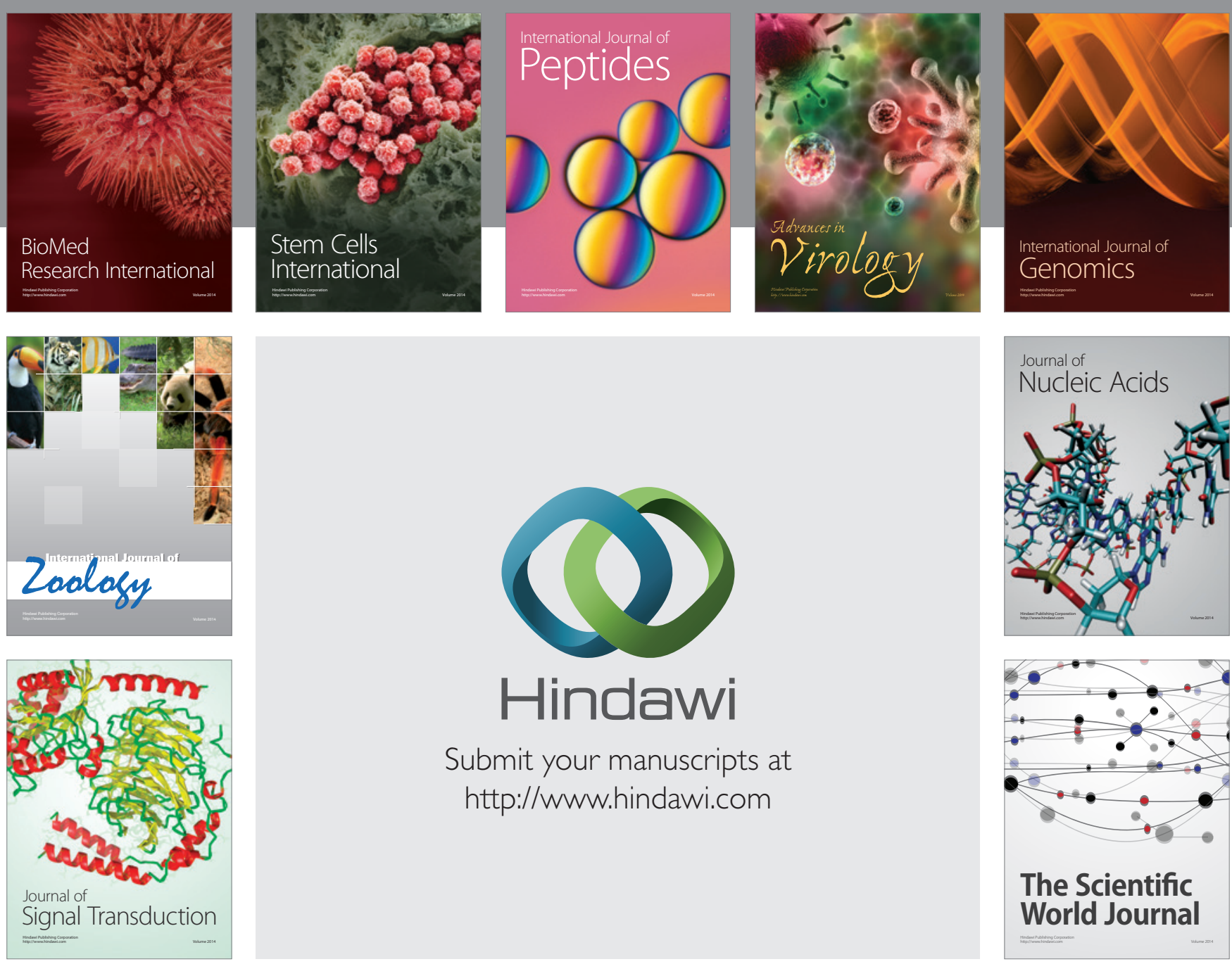

Submit your manuscripts at

http://www.hindawi.com
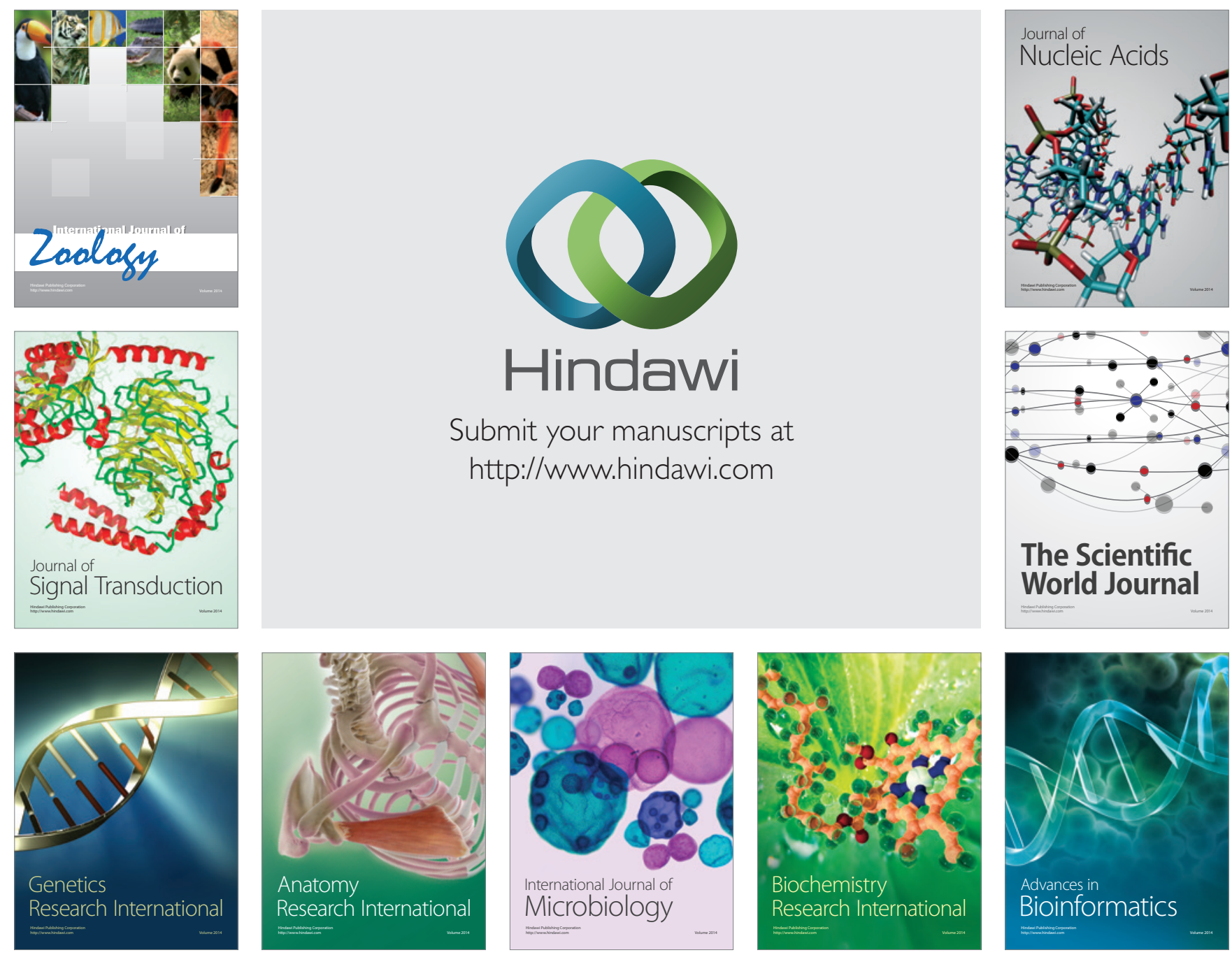

The Scientific World Journal
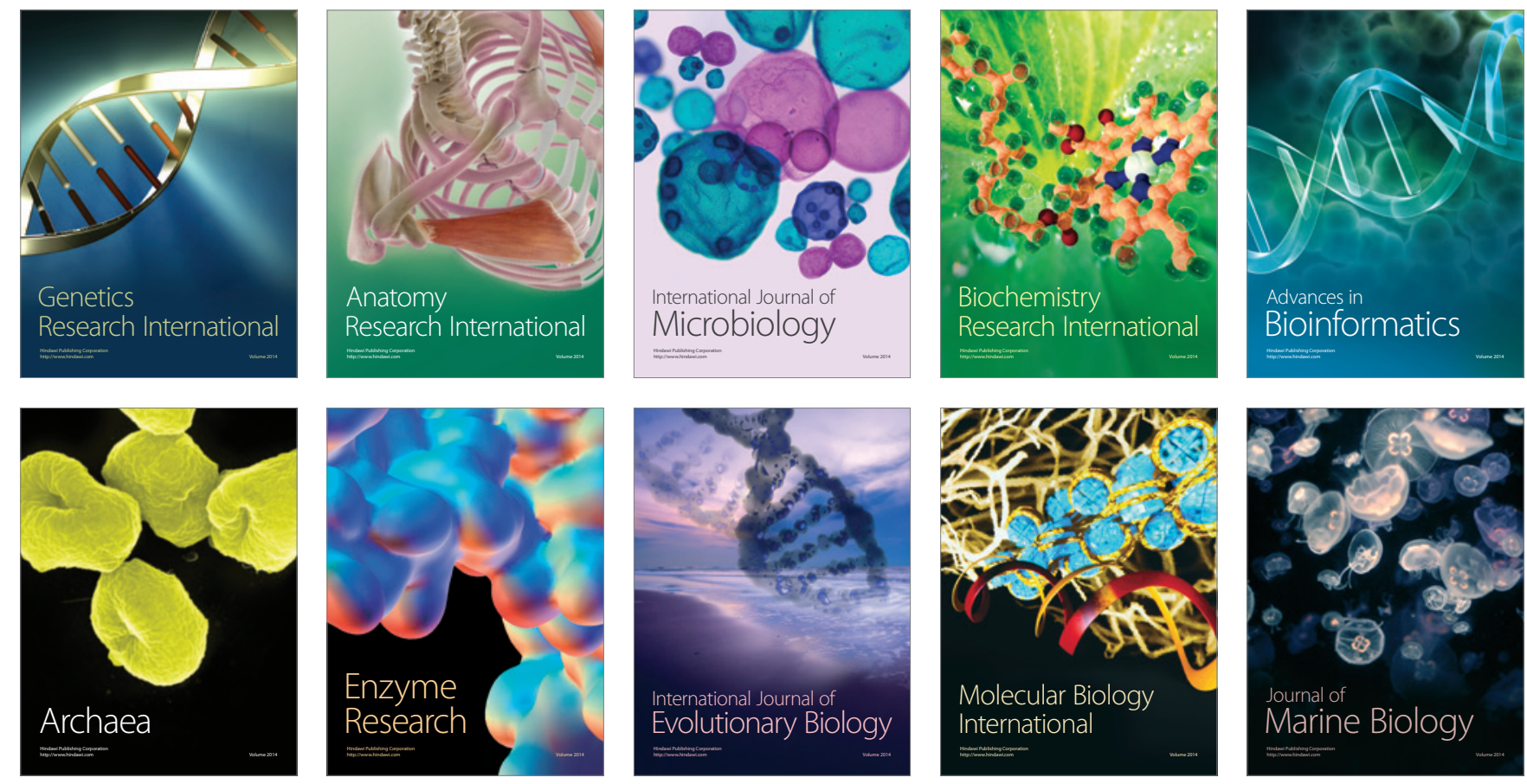